\title{
Internationalization and CSR reporting: evidence from US companies and their Polish subsidiaries
}

\author{
Charles H. Cho
}

Schulich School of Business, York University, Toronto, Canada

Joanna Krasodomska

Cracow University of Economics, Krakow, Poland

Paulette Ratliff-Miller

Grand Valley State University, Allendale, Michigan, USA, and

Justyna Godawska

AGH University of Science and Technology, Krakow, Poland

\begin{abstract}
Purpose - This study examines the internationalization effects of corporate social responsibility (CSR) reporting, specifically aiming to identify and compare the CSR reporting practices of large US multi-national corporations (MNCs) and their Polish subsidiaries.

Design/methodology/approach - Based on content analysis and using a disclosure index, the authors examined the CSR information posted on, or linked to, the corporate websites of a sample of 60 US-based MNCs and their subsidiaries operating in Poland.

Findings - The findings indicate that US companies, despite operating in a less regulated environment, had more extensive disclosure than their Polish subsidiaries and covered more CSR-related topics. CSR disclosures within the US subsample were analogous in volume and detail. By contrast, only about half of Polish companies provided CSR disclosures, which were more diverse in volume and in the types of activities disclosed. The authors did not find a significant positive correlation between the CSR disclosures of the two subsamples.

Originality/value - The study contributes to the literature on internationalization processes and sustainability practices. It provides insights into the CSR reporting of companies located in Central and
\end{abstract}

(C) Charles H. Cho, Joanna Krasodomska, Paulette Ratliff-Miller and Justyna Godawska. Published by Emerald Publishing Limited. This article is published under the Creative Commons Attribution (CC BY 4.0) licence. Anyone may reproduce, distribute, translate and create derivative works of this article (for both commercial and non-commercial purposes), subject to full attribution to the original publication and authors. The full terms of this licence maybe seen at http://creativecommons.org/ licences/by/4.0/legalcode

The authors would like to thank the participants of the 7th North American Congress on Social and Environmental Accounting in Toronto and the 42nd European Accounting Association Congress, in Paphos for their helpful comments and suggestions. This work was supported by the National Science Centre, Poland under Grant number 2019/33/B/HS4/00998. Charles Cho also acknowledges the financial support provided by the Erivan K. Haub Chair in Business and Sustainability at the Schulich School of Business. 
MEDAR

29,7

Eastern European countries. The findings also have implications for policymakers in incentivizing the enhancement of the reporting disclosure practices of companies.

Keywords Corporate social responsibility (CSR), CSR reporting, Institutional theory, Internationalization, Multi-national corporations and subsidiaries, Sustainability reporting, Poland, USA

Paper type Research paper

\section{Introduction}

The extensive globalization of markets has increased the worldwide demand for corporate social responsibility (CSR) and transparency for investors and the market in general (Martínez-Ferrero and Frías-Aceituno, 2015). However, CSR implementation varies from country to country and is influenced by specific factors. Prior studies have demonstrated significant cross-national differences in the approaches taken by companies when addressing CSR-related problems, focusing particularly on the differences between developed and emerging markets (Agnihotri and Bhattacharya, 2019).

The CSR concept was originally developed in the US, stemming from social and environmental concerns that arose in the late 1960s and early 1970s. However, European countries have become more actively involved in CSR development. While CSR resonated strongly in parts of Western Europe, it only slowly took root in Central and Eastern Europe (CEE), where it is now perceived as a "hot topic." Large public companies in the region are increasingly compiling CSR reports based on international reporting standards. Simultaneously, many small- and medium-sized enterprises (SMEs) lack the knowledge and experience to effectively implement generally accepted CSR practices. As subsidiaries of multi-national corporations (MNCs) headquartered elsewhere often adopt the most advanced CSR practices, they influence the development of CSR in the region. Such subsidiaries usually apply centrally managed CSR, customized to local laws and regulations (Feltham, 2016).

Multi-country CSR studies are popular in the accounting literature, but according to de Villiers and Marques (2016), including a wide and diverse range of countries in such analyzes may lead to situations in which the results could potentially be driven by a few outlying country-level measures. We, therefore, believed that more focused comparative studies based on two countries were also needed. Some authors have already taken this approach to provide new insights into CSR-related issues in Australia and South Africa (de Villiers and Alexander, 2014), the UK and the US (Brammer and Pavelin, 2005), Australia and New Zealand (Farooq and de Villers, 2019), Brazil and Sweden (Mazboudi et al., 2020) and Poland and Romania (Dumitru et al., 2017). However, to the best of our knowledge, studies comparing CEE countries with non-CEE/nonEuropean Union (EU) countries are non-existent.

The purpose of this study is to examine the internationalization effects of CSR reporting. More specifically, we aim to identify and compare the CSR reporting practices of large US MNCs and their Polish subsidiaries. We relied on the growing literature linking CSR and institutional theory (Bondy et al., 2012) and used it as a theoretical underpinning, well-suited to cross-country research. Institutional theory helps to explain why organizations are becoming more homogeneous (DiMaggio and Powell, 1983). We argue that it can also help in understanding the behavior of companies located in two countries that are strongly linked by economic relations but, simultaneously, differ with respect to CSR origins, regulations and practices - hence, it could provide relevant insights into the CSR and sustainability literature.

Poland is one of the largest countries in the CEE region. The country abandoned communism in 1989 and, in 2004, joined the EU. The dynamic development of sustainability practices in Poland (since about 2006) resulted from an influx of foreign investors - with the US being one of 
the largest in Poland (U.S. Department of State, 2020)[1]. We aimed to identify the relationship between the CSR reporting of US companies and that of their Polish subsidiaries. We analyzed the CSR disclosures of 120 companies comprising 60 US-based MNCs and their 60 subsidiaries operating in Poland. We divided the CSR issues into the following categories:

- Environmental impact.

- Employees and work environment.

- Relationships with partners.

- Community involvement, all of which related to environmental, social and employee-related matters according to Directive 2014/95/EU (EU, 2014).

We then computed a disclosure index score for each company, which was used for our analysis.

Contrary to expectations, we did not identify a positive association between the levels of CSR disclosure in the two subsamples. Our findings reveal that, while US companies have more advanced CSR practices and disclosure, they do not tend to impose their practices on their Polish subsidiaries; therefore, the diffusion of CSR reporting practices seems to involve more complex processes than simple imitation of MNCs' policies (Jamali et al., 2019). Our study contributes to the sustainability and CSR literature by investigating how internationalization processes affect CSR reporting, focusing on a specific and relatively unexplored CEE context. The findings also have implications for policymakers in developing incentives and binding regulations to enhance companies' CSR practices and disclosure. In the European setting, Directive 2014/95/EU is leading to changes in this regard (Doni et al., 2019; La Torre et al., 2020), as it requires certain large companies to report on a range of non-financial matters. However, it also permits flexibility by allowing them to use any existing framework to fulfill the new requirement (Biondi et al., 2020). As this approach proved to be rather unhelpful in meeting stakeholders' needs (EC, 2020b), the European Commission (EC) engaged in public consultation to review Directive 2014/95/EU (EC, 2020a). Their results have led to the proposal of the "new" Sustainability Reporting Directive, published on April 21, 2021 (EC, 2021). The document extends the scope of the reporting requirements to all large companies and listed companies (except listed micro-companies); specifies in more detail the information they should report in their management reports (no other option is possible) and requires limited assurance on the disclosures provided. Furthermore, the European Financial Reporting Advisory Group will be responsible for developing EU sustainability-reporting standards. It appears that changes in the EU reporting landscape are forthcoming and new insights into approaches to CSR reporting of companies other than large public interest entities might be informative.

The paper is organized as follows. Section 2 presents the literature review on MNCs, CSR and internationalization processes. Section 3 provides the contextual background of CSR development in the US and Poland. The theoretical framework and research question are presented in Section 4 and the empirical study design in Section 5. Section 6 contains the discussion, research limitations and suggestions for further investigation.

\section{Literature review}

Prior literature has considered MNCs to be pioneers of economic and social progress, as they are able to initiate advances and improvements in social issues in the different areas in which they operate (Porter and Kramer, 2011). MNCs generally operate in different countries and regions with diverse institutional profiles and development levels (Kostova et al., 2008). Through internationalization, they can respond to the demands of stakeholders in the different contexts and markets in which they operate, thereby promoting an image of responsible, legitimate, transparent and committed entities (Christmann, 2004). The 
MEDAR 29,7

importance, growth and increasing visibility of MNCs has been associated with increasing pressure for and expectations of, CSR activity across the spectrum of their operations (Eweje, 2006; Mohan, 2006). Aguilera-Caracuel et al. (2017) noted that MNCs can strengthen their internal organizational structures by extending their business models beyond their boundaries and efficiently transferring their best practices and policies through their management standards. As Jamali (2010b) pointed out, this is particularly true in the case of developing countries where MNCs are increasingly expected to fill gaps caused by outdated or non-existent rules (Matten and Crane, 2005). In doing so, they are likely to face pressure to adapt to the subsidiaries' local environments while simultaneously striving for consistency within their global operations (Belal and Owen, 2007; Ismaeel and Zakaria, 2019; Jamali, 2010b).

As Bondy and Starkey (2014) argued, some firms believe that using an internationalization strategy is a desirable practice. This attitude is evidenced by their advertising (e.g. HSBC advertises itself as "the world's local bank"). The rhetoric associated with "being local worldwide" (Belanger et al., 1999) has also been increasingly used in different forms of CSR communication. Perspectives have differed on whether MNCs should use centralized CSR strategies or develop them locally in consultation with stakeholders (Muller, 2006). While global strategies may be more proactive, efficient and integrated, they often lack ownership and legitimacy at the local level. By contrast, decentralized strategies, while locally responsive, may be fragmented or ad hoc. According to Husted and Allen (2006), communities that demand CSR constitutes the key difference between global and local MNCs' strategies. Local CSR relates to a company's obligations based on the expectations and standards of the local community; global CSR concerns a firm's obligations based on macro norms or universal standards by which all societies can be held accountable (Husted and Allen, 2006; Jamali, 2010b). When the level of CSR development between an MNC's country of origin and the country in which its subsidiary is based differ (as there is less public pressure), subsidiaries might prefer to lower the policy standards rather than adopt the higher standards of the MNC's country of origin (Duran and Bajo, 2014).

MNCs are facing increasing pressure on two fronts, from the need to implement good corporate practices - including CSR - and the demand for more transparency and disclosure (Kaymak and Bektas, 2017). Many studies have examined MNCs' strategies for addressing sustainability (Burritt et al., 2020), but to date, little attention has been paid to how they communicate their CSR efforts. As Wanderley et al. (2008) argued, MNCs and their local subsidiaries face challenges in communicating with diverse stakeholder groups. Such communication with stakeholders is performed through various communication channels, including annual reports, sustainability reports and the internet. These channels are not mutually exclusive; for instance, annual reports or sustainability reports could be provided on a website and social media can be used to direct stakeholders to them (Lodhia, 2018). The internet is increasingly a main tool for CSR information disclosure. Companies use it to publicize more information less expensively and faster than ever before; thus, corporate websites provide an official perspective regarding CSR within corporations for all their stakeholders.

According to Kolk and Fortanier (2013), internationalization is expected to force firms to voluntarily disclose more information, in both volume and scope. MNCs that are diversified across geographical markets have more varied stakeholder groups. They face potentially stronger and more diverse attacks on their legitimacy, driving them to voluntarily disclose more information to manage and maintain their legitimacy and reputation. The authors assumed that the diversity of regulatory requirements, as well as the array of cultures and employee values and interests, would lead firms to choose the highest, rather than the lowest, "common denominator." When a foreign MNC, with headquarters based in a country with developed CSR structures, enters a market where CSR is embryonic, it might be 
assumed that it will impose its own practices on the local divisions (Dyduch and Krasodomska, 2017).

Interestingly, prior research has revealed differences in CSR disclosure at the country level, and between domestic companies and MNCs' subsidiaries within the same country (Chapple and Moon, 2005). Kolk and Fortanier (2013), who focused on environmental disclosure, argued that the relation between internationalization and voluntary environmental disclosure is essentially a "balancing act" between institutional pressure from the home and host countries. According to them, a few studies on the determinants of voluntary disclosure have included internationalization in their models, but generally as a control variable, with mixed findings. Chapple and Moon (2005) and Araya (2006) suggested that firms with international sales orientations or foreign ownership are more likely to provide disclosures. Murcia and Souza (2010) found that internationalization had a positive relation with CSR disclosure in Brazilian companies. According to Dyduch and Krasodomska (2017), only one indicator of a company's internationalization (foreign capital share) turned out to be positively related to environmental disclosure. Amoako et al. (2017) examined the content of CSR reporting communicated through the websites of plants located on five continents, which belonged to the same MNC operating in the mining sector. Despite similar headings used on the plants' websites, the content of the reports differed and these differences appeared to result from the institutionalization of location-specific characteristics, including management discretion, legislation and societal pressures influencing sustainability reporting.

As Beddewela and Herzig (2013) pointed out, despite a great increase in social accountability pressure on MNCs, which has been followed by diverse stakeholder demands across different countries and by varying regulatory and governance systems (Ite, 2004; Kolk, 2008), little is known about the CSR reporting practices of MNCs' subsidiaries operating in less developed countries and their responses to these pressures (Islam and Deegan, 2008; Jamali, 2010a; Meyer, 2004).

\section{Theoretical underpinning and research question}

The CSR strategies of MNCs have been mostly explained through two main theoretical lenses - institutional theory (Matten and Moon, 2008) and stakeholder theory (Brammer and Pavelin, 2005). While both theories can provide interesting insights, aspects of localization versus standardization in MNCs' CSR activities have not been given systematic attention in this literature; hence, the potential determinants of specific subsidiaries' strategies remain largely unexplored.

As Dögl and Behnam (2015) indicate, institutional theory has previously been applied to analyze CSR issues in developed countries (Egri and Ralston, 2008; Farooq and de Villiers, 2019; Matten and Moon, 2008) or developing countries (Darnall et al., 2010) and we believe it is well-suited to cross-country research, given the overlaps and distinctions between countries. This theory considers the forms adopted by organizations and tries to explain why organizations become homogeneous within an organizational field (DiMaggio and Powell, 1983). It perceives companies as open systems that change in response to social and institutional processes in their environment to legitimize their actions. According to Oliver (1997, as cited in Deegan and Unerman, 2011), institutional theory perceives organizations as operating in a certain social framework - standards, values and "taken for granted" assumptions about what is appropriate or acceptable economic behavior. Businesses succumb to institutional pressures because they are rewarded with increased legitimacy, access to resources and the ability to survive (Scott, 1987). 
MEDAR 29,7

The key dimension of institutional theory is isomorphism, defined as a constraining process of the resemblance of one unit of the population to other units operating in the same environment. DiMaggio and Powell (1983) suggest three types of isomorphism processes, namely, coercive, mimetic and normative. Coercive isomorphism is a response to government regulations and regulatory pressure by which conformity is imposed on social actors (Tran and Beddewela, 2020). Mimetic isomorphism, which occurs predominantly under conditions of uncertainty, describes how organizations in one organizational field try to model their behavior by imitating others (their actions, structures and practices) to enhance their legitimacy or achieve success. Normative isomorphism describes the pressure on executives during their professional formation and manifests in the fact that professional backgrounds and membership in professional associations make the managers of organizations operating in the same field resemble one another (Wróbel, 2011). Normative elements influence firms' behavior through the use of soft laws or ethical criteria (Tran and Beddewela, 2020). DiMaggio and Powell's (1983) work was elaborated upon by Scott (2008) and used by Tran and Beddewela (2020), who described three pillars underpinning institutional order, namely, regulative (pressure exerted by country-level legal systems and regulations); cultural-cognitive (pressure caused by the national culture) and normative (pressure from international standards such as the Global Reporting Initiative [GRI] in the CSR context and business associations).

In our study, we follow Matten and Moon (2008), who suggests that "new institutionalism” provides a helpful theoretical perspective for understanding MNCs' CSR strategies. According to them, "new institutionalism has been informed by the homogenization of institutional environments across national boundaries and has indicated how regulative, normative and cognitive processes lead to increasingly standardized and rationalized practices in organizations across industries and national boundaries" (Matten and Moon, 2008, p. 411). Mimetic isomorphism processes, as noted above, occur predominantly under conditions of uncertainty when firms try to model their behavior on that of others. In a business climate characterized by increased uncertainty and progressively complex technologies, managers tend to consider practices as legitimate if they are viewed as "best practice" in their organizational environments. We believe that similar trends can be observed regarding CSR development in CEE countries.

Brammer et al. (2012) noted that CSR appears to be institutionalized within MNCs' transnational organizational structures. As previously mentioned, CSR originates from and is dominated by, large MNCs - many of which have fairly widespread CSR activities, leading to institutional mechanisms by which these companies govern their global operations. These mechanisms take the form of codes of conduct, ethics or practice and form sets of rules and norms by which CSR practices are governed throughout organizations (Sharfman et al., 2004). Another element of transnational governance and CSR focuses on how national institutions in the home or host country of an MNC shape and institutionalize CSR practices. As Brammer et al. (2012) argued, taking into consideration the "country-oforigin effect" in institutional theory (Harzing and Noorderhaven, 2003), it is obvious that a number of CSR practices reflect the norms and values of Western, well-developed countries, but have led to widespread changes in firms and institutions in developing countries, including CEE countries (Muthuri and Gilbert, 2010).

As Ismaeel and Zakaria (2019, p. 92) noted: "Sustainability reporting has emerged and developed as a distinct practice at the global level. Its regulation, legitimation and motivation are mainly global. However, local norms and needs influence the practice as well." According to this reasoning, MNCs, parent companies and their subsidiaries at any point in time are likely to experience many "push and pull" forces that determine the extent 
of the localization versus standardization of their CSR strategies. In other words, global CSR may be transferred to developing countries, but may also be diluted along the way by specific subsidiary endowments and host market characteristics, including managers' behavior. On the one hand, local managers might experience great pressure to follow parent companies' instructions due to their dependence on parent companies' resources, such as capital, technology or experience. On the other hand, many subsidiary managers are too distant and detached to follow their parent companies' policies and sustain the collective organizational identity (Park, 2018).

A question then arises regarding the extent to which subsidiaries in developing countries follow best practices regarding CSR reporting implemented by the MNCs that control them. Our study addresses this question, responding to calls for more in-depth studies examining CSR disclosure among MNCs and their subsidiaries (Gray et al., 1996; Islam and Deegan, 2008). We focus particularly on two countries - Poland and the US - and formulate our research question as follows:

$R Q$ : What are the internationalization effects of US parent companies and their Polishbased subsidiaries on CSR reporting?

\section{Contextual background - corporate social responsibility in the US and Poland}

\subsection{Corporate social responsibility in the US}

In the US, the concept of CSR has been discussed, as Howard R. Bowen published Social Responsibilities of the Businessman in 1953 (Bowen, 1953). Definitions of CSR have varied and developed from "social responsibility" or "public welfare" to environmental concerns, diversity and climate change. Proponents of CSR hold that businesses should do more than simply earn profits for their shareholders. To help investors identify companies that take CSR activities seriously and are not simply "greenwashing," sustainability ratings have been created by publications such as Forbes magazine. The Dow-Jones Sustainability Index is among the many indices that rank companies to assist investors to invest in socially responsible companies.

The US is a common-law country, the business culture of which is perceived as shareholder-oriented (Holder-Webb et al., 2008; de Villiers and Marques, 2016). Shareholders are considered the most important stakeholder group and the needs, expectations and pressures of other groups have less influence on corporate activities (Simnett et al., 2009). Therefore, regulations regarding CSR - a stakeholder-oriented phenomenon - are not expected to be as well-developed as in code-law (stakeholder-oriented) countries, as USbased firms are less likely to report sustainability information to obtain the approval of their stakeholders. While the bulk of CSR disclosure in the US is voluntary, the Securities and Exchange Commission (SEC) has mandated disclosure. Regulation S-K (1982) applies to public companies and requires disclosure of the material effects of compliance with federal, state and local environmental laws on their capital expenditures, earnings and competitive positions (Item 101). It also includes disclosure of pending legal proceedings relating to environmental laws (Item 103), as well as known trends, events or uncertainties (including environmental matters) that could have a material effect on financial conditions (Item 303). In 2010, the SEC issued Commission Guidance Regarding Disclosure Related to Climate Change, Exchange Act Release. While this guidance added no new requirements, it encourages firms to be mindful of climate change and greenhouse gas emissions in applying the former rules (Grayson and Boye-Williams, 2011). 
MEDAR 29,7

Despite the absence of requirements, the number of companies that choose to report has grown dramatically. According to the Governance and Accountability Institute's 2018 report, 85\% of S\&P 500 companies published sustainability reports in 2017 (Governance and Accountability Institute, Inc, 2018). This was a $425 \%$ increase in only six years (20\% reported in 2011). An examination of US annual reports and CSR reports shows that the degree of detail firms provided in their reports of CSR activities varies widely. While formats for the reports differ, the two most recognized and widely used guidelines for reports are the GRI and the UN Global Compact. US companies are facing increasing pressure from stakeholders to provide CSR information. In January 2018, Larry Fink (CEO of BlackRock, Inc.) published an annual letter to CEOs focusing on the demands of shareholders for firms to "respond to broader societal challenges" (Fink, 2018). It stated: "To prosper over time, every company must not only deliver financial performance, but also show how it makes a positive contribution to society." When BlackRock - the world's largest asset management company - began making investment decisions with CSR issues in mind, other firms began to follow. GreenBiz Group's (2018) annual survey of sustainability professionals concluded that sustainability programs were impacted by pressure from customers and investors looking for more than just pretty pictures and stories of what the company had done in the community. They used information about environmental, social and governance issues to create strategies for growing their businesses. Voluntary CSR-related disclosure might also be reinforced by the characteristics of the US national culture. Based on Hofstede's (2020) cultural dimensions and the value of the Secrecy Index developed by Hope et al. (2008)[2], the US is ranked as one of the most transparent countries in the world with a score of minus 5 .

\subsection{Corporate social responsibility in Poland}

Poland has the sixth-largest economy in the EU and has long had a reputation as a businessfriendly country with sound macroeconomic policies. Since 1990, Poland has pursued a policy of economic liberalization. Regarding environmental issues, Poland's decreased emphasis on heavy industry and the increased environmental concern of post-communist governments, have improved the environment; however, air pollution remains serious because of emissions from coal-fired power plants and the resulting acid rain has caused forest damage. Water pollution from industrial and municipal sources is also a problem, as is the disposal of hazardous waste (CIA, 2018).

Encouraging responsible behavior in Polish companies has never been an easy process and has gone through several stages, resulting from the socialist heritage of this country's past. Mainly because of the word "social" in its name, CSR was seen in former socialist countries as a type of socialist renaissance, which, given the desirable transition to a market economy, was considered a threat (Popowska, 2016). CSR has also been and is still, perceived by many as simply a charitable action, resulting in costs rather than benefits.

Poland's legal system, like those of other countries in Continental Europe, is based on code law, implying a stakeholder-oriented model. It is associated with comprehensive laws giving stakeholders legitimate interests and, consequently, a more significant influence on firms' sustainability behavior (Tran and Beddewela, 2020). Poland, as an EU Member State, is required to adopt EU directives. Regarding the disclosure of social and environmental issues, the Polish Ministry of Finance implemented Directive 2014/95/EU on the disclosure of non-financial and diversity information by certain large undertakings and groups in December 2015 (Act on changing the Accounting Act of 15 December 2016, 2017). The changes in the accounting laws were not especially welcomed by the Ministry, which perceived the additional non-financial disclosures as an administrative burden. According to the new law, large public-interest entities with an average of 500 or more employees are obliged to prepare non-financial statements containing information relating to, at a 
minimum, environmental matters, social and employee-related matters, respect for human rights and anti-corruption and bribery matters. Reporting requirements took effect at the start of the fiscal year on or after January 1, 2017. Because of this change, CSR disclosures became mandatory for about 300 companies [Forum Odpowiedzialnego Biznesu (FOB), 2017]. For a few, this was not a new exercise, as they had compiled non-obligatory social reports for several years. Only 40 reports were included in the GRI database in 2017 (GRI, 2020). Three of the reporting firms were SMEs, seven were MNCs operating in Poland and the rest were large Polish companies. However, Poland was the CEE EU Member State with the highest number of such reports and, according to Matuszak and Różańska (2017), the Directive requirements were expected to positively influence their quality (Krasodomska et al., 2020).

The Polish Government noted that the development of CSR has been closely associated with the influx of foreign investors (Gruszewska and Wakuluk, 2012). This constituted an indirect admission of some responsibility for the slow and controversial implementation of CSR initiatives in the country. A survey[3] of US companies operating in Poland concluded that they tended to implement their own CSR policies. Many companies ran programs to feed children and some engaged in programs aiming to engage excluded social groups back into the labor market. Other CSR areas mentioned in the survey included blood donation, protection of cultural heritage and financial education. The CSR picture that emerged suggested that CSR in Poland, although evident in companies' actions and discourse, related to a large extent to corporate giving (i.e. sponsorship and charity). Companies, therefore, operate in an uncertain environment caused by the lack of strong government support for CSR and awareness of how to implement the concept into corporate strategies and benefit from it.

Taking into consideration the Polish national culture dimensions measured by Hofstede (2020), the Ministry's and firms' decisions not to report more information than was required by law seem justified to some extent. Hope et al.'s (2008) Secrecy Index gave Poland a score of 101 , which was relatively high.

\section{Empirical analysis}

\subsection{Sample}

Our sample consists of 120 companies, including 60 US-based MNCs and their 60 subsidiaries operating in Poland (Appendix 1). The companies were selected from a report compiled by KMPG and American Chambers of Commerce in Poland (2018). The report included two lists - a list of 56 of the 100 largest US companies (those with Polish subsidiaries) and a list of the most significant US investors in Poland (31 companies). From these 87 companies, we excluded duplicates (those on both lists) and companies with Polish subsidiaries that were no longer operating in 2018. This reduced the sample to 72 companies. As 12 of these did not have websites, this reduced our final sample size to 60 pairs of companies.

\subsection{Method}

Most Polish companies in the sample are limited liability companies for which CSR disclosures are voluntary. Only four of the Polish companies published a simplified CSR report (as a separate file); hence, we primarily analyzed the information disclosed on corporate websites (in Polish). The US companies were all large MNCs for which reporting was voluntary. While a few of the companies had little or no CSR disclosure, many of the companies provided extensive information on numerous aspects of CSR. We gathered data for the analysis from publicly available information on the companies' websites and in GRI reports (typically linked to the websites)[4]. As both were accessible on the internet, we followed de Villiers and Alexander (2014) and treated disclosures from both sources as equivalent. 
MEDAR

29,7
In the descriptive stage of the analysis, we focused on the availability and volume of CSR disclosure in general. Following Maignan and Ralston (2002), we searched links to the relevant areas either on homepages or in sections providing general company information (usually entitled "Company Information" or "About Us").

We then searched for discussions about each of the CSR issues of interest included by the companies in their documents. We divided the CSR issues into the following categories[5]:

- Environmental impact.

- Employees and work environment.

- Relationships with partners.

- Community involvement.

Each of these categories consisted of multiple CSR activities in which the companies engaged. A full list of these activities is presented in Appendix 2.

Company disclosure indices were created for each category by first assigning a binary value to each item within that category. This approach is often used in the social sciences (Beattie et al., 2004; Beske et al., 2020; Garanina and Dumay, 2017; Hummel et al., 2017; Michelon et al., 2014). If the company discussed that item, the item received a score of 1 , otherwise, it received a score of 0 . The approach used was not based on pre-selected index items, as the list evolved during the content analysis. More specifically, index items were verified by a pilot study based on 20 randomly selcted Polish companies, but during the research, when new information was identified in a subsequent company's non-financial statement, it was added to the index list.

The scores for the items in each category were then totaled to obtain a point score $\left(\mathrm{P}_{\mathrm{i}}\right)$. This was repeated for each category and a total (cumulative) point score was generated.

In total, 33 activities were included in the following categories:

- $\mathrm{P}_{1}$ - environmental impact (9 items).

- $\mathrm{P}_{2}$ - employees and work environment (8 items).

- $\mathrm{P}_{3}$ - relationships with a partner (5 items).

- $\mathrm{P}_{4}$ - community involvement (11 items).

- $\mathrm{P}_{5}$ - total (cumulative) points (33 items).

The points were then used to compute the disclosure indices $\left(I_{i}\right)$ for each category (as a percentage) by taking the points in the category $\left(\mathrm{P}_{\mathrm{i}}\right)$, divided by the number of items in the category, times 100 . We used the following formulae:

$$
\begin{aligned}
& \mathrm{I}_{1}=\left(\mathrm{P}_{1} / 9\right) * 100 \\
& \mathrm{I}_{2}=\left(\mathrm{P}_{2} / 8\right) * 100 \\
& \mathrm{I}_{3}=\left(\mathrm{P}_{3} / 5\right) * 100 \\
& \mathrm{I}_{4}=\left(\mathrm{P}_{4} / 11\right) * 100 \\
& \mathrm{I}_{5}=\left(\mathrm{P}_{5} / 33\right) * 100
\end{aligned}
$$


where

$\mathrm{I}_{\mathrm{i}}=$ is the disclosure index for each company for each category.

$\mathrm{P}_{\mathrm{i}}=$ is the number of points determined for each company for each category.

This approach is consistent with the studies of Barako and Brown (2008) and TejedoRomero et al. (2017). The value of each index was expressed as a percentage ranging from $0 \%$ to $100 \%$; the higher the value, the greater the extent of CSR disclosure.

\subsection{Descriptive results}

In the first stage of our analysis, we focused on the availability and volume of the CSR disclosures. The tables below provide general information taken from the website and CSR report content analysis for each country separately.

Most of the US sample firms had extensive disclosures on their websites, as well as reports available through GRI (Table 1). In total, 85\% (51) of the US sample firms had a CSR report either on their website or available through a link. This is consistent with other large US firms, as 85\% of S\&P 500 companies published Corporate Sustainability Reports in 2017 according to the Governance and Accountability Institute, Inc. (2018). In total, 23 of the reports included (limited) assurance performed by outside parties; 5 of these audits were carried out by Big Four auditing firms. Also, nearly half of the sample firms discussed their CSR strategy, visions and/or goals, indicating their commitment to social issues.

Of the 60 Polish companies included in the sample, 28 did not provide any CSR disclosure. It should be noted that the companies included in the Polish subsample were mainly SMEs that operated as limited liability companies. Only a few were joint stock companies and two of them were publicly traded. Only five companies from our sample were large public interest entities required to disclose CSR information starting in 2017.

The approach used most often by the Polish companies was the provision of a clearly visible link on the main website page (20), followed by several separate subpages in Polish (19) (Table 2). A link to the parent website was also a common approach - 15 companies provided a link to the English language website devoted to CSR issues.

Only two companies from the Polish sample formulated their CSR strategy clearly, in Polish and only four posted a simplified version of the CSR report on their websites. Pepsico's report is 10 pages long and provided a transparent presentation of the company's CSR activities in Poland (Pepsico, 2018). Mars published a two-year 12-page summary of performance principles, including global and local (Polish) initiatives (Mars, 2018). Lear Corporation's four-page report focused only on environmental protection and workers' health and safety (Lear Corporation, 2018). Pfizer stood out for its 102-page report, which provides a detailed disclosure of CSR issues (Pfizer, 2018).

In the second stage of analysis, we focused on the content of the CSR information. Table 3 presents the CSR disclosures provided by the US companies.

For the US firms, nearly all the sample companies (58 of 60) mentioned CSR factors, including environmental impact, work environment, community involvement and (slightly

Disclosure characterstics

Clearly visible link on the main page

CSR report (PDF file)

Disclosure volume: brief comment (s)

Disclosure volume: one subpage

Disclosure volume: several subpages 
MEDAR

29,7

146

less often) relationships with partners (Table 3). Stakeholders of large firms in the US appeared to have convinced the management of the value of the expanded corporate disclosure. The variability of the CSR disclosure in the US subsample is low and none of the coefficients of variation (i.e. the ratios of the standard deviations to the means) for the disclosure indices exceeds $61 \%$. These results indicate that disclosures for US firms are analogous with respect to the types of CSR issues they chose to report.

Regarding environmental impact $\left(\mathrm{I}_{1}\right)$, firms most frequently note their efforts to reduce water usage, emissions and energy use and/or carry out waste recycling. These issues reflected what most US firms considered important regarding sustainability or social responsibility, as indicated by the highest mean score (61.48) of the four categories. Employee and work environment disclosures $\left(\mathrm{I}_{2}\right)$ focused on ethics and anti-corruption policies, volunteering and fostering a diverse workplace. The score (mean 58.75) fell slightly below that for environmental issues. Relationships with partners $\left(\mathrm{I}_{3}\right)$ resulted in the lowest score (mean 39.00), as these items (marketing, supply chain, etc.) are less common concerns for shareholders and investors in relation to CSR activities. Finally, community involvement $\left(\mathrm{I}_{4}\right.$, with a mean score of 46.36) encompasses charitable sponsorship, cultural support and educational initiatives. The low value of community involvement contrasts with Maignan and Ralston (2002), according to whom US firms' disclosures focused mostly on philanthropic programs and community involvement (e.g. quality of life and education).

Almost half of the Polish companies provided disclosures relating to local communities $(47 \%)$ and environmental impact (45\%) (Table 4). This finding is consistent with the results of Krasodomska and Godawska (2020), who identified community involvement and development, labor practices and the environment as most frequently mentioned in the disclosures of non-public entities operating in Poland. However, when we compared the disclosure indices, the extent of environment-related disclosures is the highest. CSR information about relationships with partners is presented by the lowest number of companies, in relation to the fewest items within the category, leading to the lowest score.

We noted considerable variability in CSR disclosure, with the coefficient of variation for all the disclosure indices exceeding $60 \%$. The variability of CSR disclosure in the Polish subsample is much higher than that of the US companies. The variability coefficient ratios range between $120 \%$ and $179 \%$. A few companies complemented their narrative disclosures with the use of key performance indicators, used three times regarding environmental matters and three times regarding employees. Regarding relationships with partners and relationships with local communities, each was reported only once.

\subsection{Statistical analysis}

In line with the assumptions of new institutionalism (Matten and Moon, 2008), we expected to see CSR practices being transferred between US parent companies and their Polish-based

Disclosure characterstics

Clearly visible link on the main page and separate subpage(s) in Polish

Simplified CSR report (PDF file, in Polish)

Clearly visible link on the main page and separate subpage(s) in English

(US company's website)

Link to the US company's CSR report

Disclosure volume: brief comment (s)

Disclosure volume: one subpage

Disclosure volume: several subpages
Frequency

20

4

15

4

6

6 19 
MEDAR

29,7

148

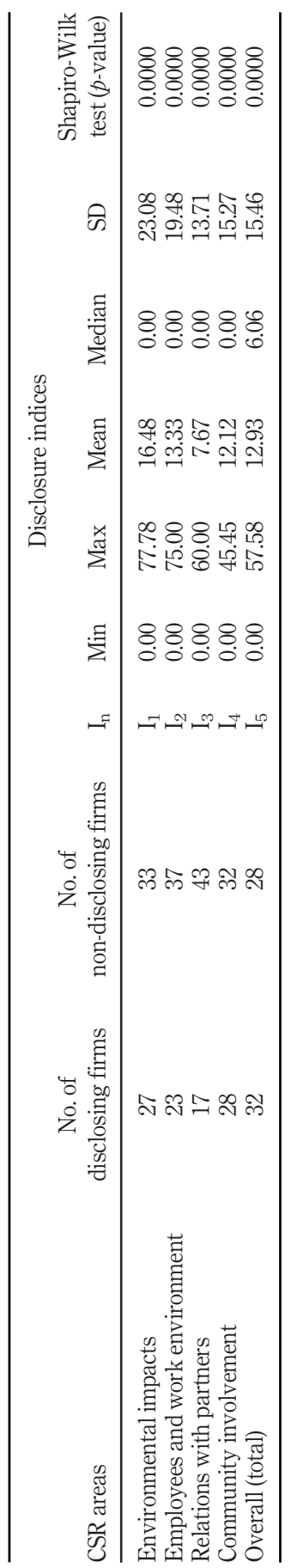

Table 4.

CSR disclosures provided by Polish companies $(n=60)$ 
subsidiaries. However, we were also aware of the "push and pull" forces that might have impacted the internationalization processes (Ismaeel and Zakaria, 2019). To identify these effects, we conducted a statistical analysis. Because of a non-normal distribution of variables (as indicated by the Shapiro-Wilk test), we investigated the significance of the differences between the CSR disclosures provided by the subsample of Polish-based US subsidiaries and the subsample of their US parent companies using the nonparametric Mann-Whitney $U$ test. The total disclosure level, as captured by $I_{5}$ (total of all four categories) and disclosure levels with regard to individual categories (environmental impact $\left[I_{1}\right]$, employees $\left[I_{2}\right]$, relations with partners $\left[I_{3}\right]$ and community involvement $\left[I_{4}\right]$ ), are significantly different for the analyzed subsamples (Table 5). The index values for the 120 companies included in our sample are presented in Appendix 1. This allows to conclude that the CSR disclosures are different but still does not exclude the possibility to identify similarities between parent and subsidiary as a pair. This assumption is in line with the new institutionalism, according to which isomorphic pressures occur. They force companies to become homogeneous within an organizational field beyond national boundaries (DiMaggio and Powell, 1983; Matten and Moon, 2008; Brammer et al., 2012).

To identify any similarities between the CSR involvement of US-based companies and their respective Polish subsidiaries, we used the Spearman rank correlation. We found no correlation between the overall disclosures (as captured by the $\mathrm{I}_{5}$ ) (Table 6) and no correlations between the values of other indices $\left(\mathrm{I}_{1}-\mathrm{I}_{4}\right)$. This means that, contrary to our expectations, disclosures on environmental issues, employees, relations with partners and community involvement (expressed, respectively, by the $\mathrm{I}_{1}-\mathrm{I}_{4}$ indices) of US and Polish companies are not related.

The $p$-values included in Table 6 indicate that, even at the 0.10 significance level, the correlation between the values of each pair of indices $\left(\mathrm{I}_{1}-\mathrm{I}_{5}\right)$ for both countries is not statistically significant.

Therefore, the results suggest no relation between the levels of CSR disclosure of Polandbased US subsidiaries and their US parent companies. As in Maignan and Ralston (2002), our sample companies did not experience the same pressure to appear socially responsible and use diverse means to convey socially responsible images. This result is also consistent

\begin{tabular}{lrrr}
\hline Indices & $Z$-statistics & $p$-value & \\
\hline $\mathrm{I}_{1}$ (environmental impacts) & -7.1067 & 0.0000 & \\
$\mathrm{I}_{2}$ (employees and work environment) & 7.8441 & 0.0000 & Table 5. \\
$\mathrm{I}_{3}$ (relations with partners) & 5.5636 & 0.0000 & The results of the \\
$\mathrm{I}_{4}$ (community involvement) & 7.0463 & 0.0000 & Mann-Whitney U \\
$\mathrm{I}_{5}$ (overall/total) & 8.0016 & 0.0000 & test \\
\hline
\end{tabular}

\begin{tabular}{lcrrr}
\hline Indices & Spearman rank correlation coefficient & p-value & \\
\hline $\mathrm{I}_{1}$ (environmental impacts) & 0.1375 & 0.2947 & & Table 6. \\
$\mathrm{I}_{2}$ (employees and work environment) & 0.0961 & 0.4650 & The results of the \\
$\mathrm{I}_{3}$ (relations with partners) & 0.1450 & 0.2691 & Spearman rank \\
$\mathrm{I}_{4}$ (community involvement) & 0.0386 & 0.7697 & correlation \\
$\mathrm{I}_{5}$ (overall/total) & 0.2066 & 0.1133 & \\
\hline
\end{tabular}


MEDAR 29,7 with Belal and Owen (2007), who argue that MNCs in the West are often criticized for ignoring their less-powerful stakeholders in developing countries; while they report extensively in their home countries, they do not in their operating subsidiaries in the host countries. The inability to identify such a relation does not necessarily mean that the mimetic, regulative and normative pressures do not influence the CSR reporting strategies of the sample companies. It only suggests that such influences might be far more complicated and need further and more detailed investigation.

\section{Discussion and conclusion}

While interest in CSR practice and disclosure is increasing throughout the world, its development varies across countries. European countries are perceived as quite advanced in this area, but Europe remains a very diverse region. The eastern part of Europe lags far behind the western part, mainly due to its communist past (Albu et al., 2021; Fifka, 2013). CEE members of the EU generally prefer to adopt CSR practices that function in more developed regions of the world rather than invent new ones of their own. Like other goods and services, CSR good practices are incorporated by Polish firms in response to the influx of foreign capital (Gruszewska and Wakuluk, 2012). Poland is the largest beneficiary of US investments among CEE countries. US companies create jobs and are involved in local CSR activities, such as achieving gender parity or developing cooperation with Polish universities (KMPG and the American Chamber of Commerce in Poland, 2018). In this study, we focused on Polish-US relationships in terms of CSR disclosure practices. Because CSR has been practiced for decades in the US and the level of CSR disclosure is higher there than in the CEE countries, we investigated whether the Polish subsidiaries would adopt the practices of the US parent companies (internationalization). Despite the increasing interest in, and discussion about, CSR in Poland (in the context of the financial crisis and, more recently, due to the implementation of the EU Directive - Bachnik et al., 2020; DługopolskaMikonowicz et al., 2019; Dyduch and Krasodomska, 2017; Matuszak and Różańska, 2017, 2021), the code-law-based system and the advent of stricter regulations, US companies are far more advanced with regard to CSR disclosure than their Polish subsidiaries. According to our findings, the US companies in the sample had higher levels of CSR disclosure in both volume and variety of activities. Most of them provided extensive disclosures on their websites and in GRI reports. Their CSR information was also quite homogenous. By comparison, only four firms included in the Polish subsample prepared any kind of CSR report (none of them followed GRI guidelines). Almost half of the companies provided no CSR disclosures on their websites at all. Those that provided them did so in a very diverse manner; that is, the disclosures were non-uniform in their volume and types of activities.

We did not observe patterns of the US CSR practices being diffused to Poland as a manifestation of internationalization. Our study suggests that CSR practices are diluted along the way according to each subsidiary's characteristics and because of the different levels of CSR implementation. Polish subsidiaries are managed as autonomous units allowed to run their operations as they see fit. This leads to a broader organizational culture in which senior positions are not dominated by nationals from the parent companies, potentially leading to a better understanding of local needs and demands. We share the view that, despite the increased focus on CSR and disclosure as evidenced by the obligation forced on some companies by the EU Directive, the needs and demands of Polish stakeholders regarding CSR disclosures did not manifest themselves as urgent and important or exert pressure in this regard on Polish companies.

Given the differences between US and European CSR reporting (Danko et al., 2008), other possible factors seem to influence the CSR practices of Poland-based US subsidiaries, 
possibly including the characteristics of companies themselves, such as size, industry or corporate governance mechanisms or general approaches toward CSR in the country. Weak institutional support for CSR reporting might also have been an important factor. Cahan et al. (2016) recently found higher levels of CSR disclosure in countries where nation-level institutions are strong. The need to follow EU policy undoubtedly led to Poland's increased inclusion of CSR in business practice, and of non-financial information in corporate reporting; however, the Directive itself was not strongly promoted by the Polish Government, and it was perceived by many as an administrative burden. Costs involved in the disclosure process or less demanding investors may also explain why Polish companies do not follow their US parent companies' example. Several other factors like those observed in other CEE countries might have prevented the development of CSR in Poland; for instance, the concept of CSR is still perceived by many as vague, elusive and contestable; civil society is not well-organized; companies do not face strong and constant pressure from other stakeholders (including employees, suppliers and customers) and the press has yet to assume the role of watchdog. Institutions and systems that are the foundation of CSR in Western Europe and the US are comparatively weak in Eastern European countries (Kemp, 2001).

In this paper, we focused on new institutionalism and, particularly, the mimetic, regulative and normative pressures that influence the CSR reporting strategies of the sample companies. According to Scott (2008), mimetic processes relate to the cultural-cognitive pressures engendered by the national culture. There are differences in the national cultures of both countries, as indicated by Hofstede (2020), especially regarding uncertainty avoidance (UA), individualism and power distance (PD). According to Hope et al. (2008), Poland is a more secretive country than the US and this cultural aspect might prevent disclosure practices from spreading. Despite the new regulations and the acceptance of soft laws (such as GRI standards), Poland is still a non-transparent country, in which sharing CSR-related information, when not required, is not a common practice. The introduction of regulations aimed at the biggest public interest entities and the debate surrounding them, including emphasizing the advantages of CSR disclosure, might not be enough to facilitate the diffusion of best practices for corporate disclosure. The concept of CSR accepted and practiced in the US, still needs to be promoted in Poland. It seems that a greater role might be assigned to civil society, which could stimulate CSR practice and disclosure by placing greater societal demands and expectations on businesses (Chapple and Moon, 2005; Wanderley et al., 2008) and to the proper education of future managers that is necessary for it to achieve wider acceptance. Increased media attention on CSR issues could also push MNCs operating in developing countries to engage more in CSR disclosure.

Our study contributes to the sustainability and CSR literature by investigating how the internationalization process affects the implementation of CSR disclosure. Previous studies investigated the internationalization of CSR strategies in a single country context, but did not focus on reporting practices and mostly used interviews in their research approach (Beddewela and Fairbrass, 2016; Beddewela and Herzig, 2013; Bondy and Starkey, 2014; Bondy et al., 2012; Jamali and Neville, 2011). Studies that made two-country comparisons focused on CSR practices, rather than reporting (Brammer and Pavelin, 2005; Mazboudi, 2020) or investigated CSR reporting in a non-parent-subsidiary context (de Villiers and Alexander, 2014; Dumitru et al., 2017; Farooq and de Villers, 2019).

Our findings also have implications for policymakers as they endeavor to incentivize the sustainability practices and CSR disclosure of companies. While US parent companies' strategies are often proactive and effective, they might require support at a local level, specifically from the government and stakeholders. There is also room for improvement 
MEDAR 29,7

\section{2}

among educators and companies' boards. The successful implementation of CSR disclosure and practice requires the support of senior management. Members of corporate boards should be motivated and positive about the benefits of increased CSR transparency, rather than focusing on the costs. Our findings may also be interesting for Polish regulatory bodies and Nongovernmental organizations (such as FOB), which deal with CSR development and might motivate companies to take a more proactive approach to improve the quality of their CSR disclosures. Such an approach is important and necessary, not only for large public interest entities' reporting as required by the EU Directive but also for other companies that might find themselves within its scope if the ongoing consultations result in such a requirement.

Our study is not without limitations. First, our sample includes 60 pairs of companies US-based MNCs and their Polish subsidiaries. We acknowledge that the small sample and limitation to one country means that the findings should be generalized with extreme caution, as this study was not meant to provide a systematic and comprehensive analysis of CSR dissemination by MNCs. The Polish subsidiaries also varied considerably regarding size, employment and industry and, as mentioned above, it may be that such firm-specific aspects were important determinants of the relations we explored in this paper. A more indepth, qualitative analysis of the best reporters' disclosures might also be relevant. The results of this study invite researchers to further explore the relations between internationalization and CSR. Future research may, therefore, explore other factors that might influence US companies' reporting policies, such as the extensiveness of their operations in Poland, the sector or industry in which they operate, the ownership structure or the degree of centralization versus decentralization. Studies may also seek to improve the general understanding of how the social responsibility standards of other, more established, host countries (and jurisdictions) in terms of reporting practices affect the CSR behavior of MNCs. Other research approaches, such as surveys or semi-structured interviews, may provide new insights into the CSR disclosure-related internal processes of MNCs and their subsidiaries. These processes could also be researched in the context of "glocalization." This new concept, stemming from the combination of globalization and localization, seems to be unexplored and might generate interesting perspectives.

\section{Notes}

1. The history of American business in Poland dates back several decades. The first US companies operated in Poland before World War II. In Communist times, despite the Cold War, American companies nevertheless managed to do business in Poland. A real investment boom occurred after 1989, with American-owned companies among the pioneering foreign investors in Poland (KPMG and the American Chamber of Commerce in Poland, 2018). Most of the companies with US capital that appeared in Poland in the first half of the1990s reinvested in the Polish market in the past decade. These are huge, well-known companies with highly recognized brands and are experienced in CSR practices.

2. The Secrecy Index is calculated as the sum of UA and PD scores less the individualism (IND) score (Hope et al., 2008). For the use of Hofstede's cultural dimensions in accounting research see also (Khlif 2016).

3. The survey was conducted on a group of 142 US companies operating in Poland (AmCham members) in January and February 2018. The respondents were asked, among other things, about their reasons for coming to Poland, their research and development and CSR activities, their employment structures and the methods they selected for entering the Polish market (KPMG and the American Chamber of Commerce in Poland, 2018). 
4. Website disclosure is increasingly used to communicate CSR-related information and provides the opportunity to disseminate a large amount of information in a relatively short time (Chong et al., 2016).

5. The coding scheme was developed based on an iterative analysis of web pages of 20 Polish companies. This preliminary study allowed us to establish the components of the four disclosure categories that formed the basis of our disclosure indices and, subsequently, our analysis.

\section{References}

Act on changing the Accounting Act of 15 December 2016 (2017), "Official journal of 2017, item 61", available at: http://prawo.sejm.gov.pl/isap.nsf/DocDetails.xsp?id=WDU20170000061

Agnihotri, A. and Bhattacharya, S. (2019), "Communicating CSR practices - role of internationalization of emerging market firms", Journal of Marketing Communications, Vol. 25 No. 4, pp. 1-20.

Aguilera-Caracuel, J., Guerrero-Villegas, J. and García-Sánchez, E. (2017), "Reputation of multinational companies: Corporate social responsibility and internationalization", European Journal of Management and Business Economics, Vol. 26 No. 3, pp. 329-346.

Albu, N., Albu, C., Apostol, O. and Cho, C.H. (2021), "The past is never dead: the role of imprints in shaping social and environmental business responsibilities in a post-socialist context", Accounting, Auditing and Accountability Journal, Vol. 34 No. 5, pp. 1109-1136.

Amoako, K.O., Lord, B.R. and Dixon, K. (2017), "Sustainability reporting: Insights from the websites of five plants operated by newmont mining corporation”, Meditari Accountancy Research, Vol. 25 No. 2, pp. 186-215.

Araya, M. (2006), "Exploring terra incognita. Non-financial in reporting corporate Latin America", Journal of Corporate Citizenship, Vol. 2006 No. 21, pp. 25-38.

Bachnik, K., Kaźmierczak, M., Rojek-Nowosielska, M., Stefańska, M. and Szumniak-Samolej, J. (2020), CSR in Contemporary Poland. Institutional Perspectives and Stakeholder Experiences, Springer International Publishing.

Barako, D.G. and Brown, A.M. (2008), "Corporate social reporting and board representation: evidence from the Kenyan banking sector", Journal of Management and Governance, Vol. 12 No. 4, pp. 309-324.

Beattie, V., McInnes, W. and Fearnley, S. (2004), “A methodology for analysing and evaluating narratives in annual reports: a comprehensive descriptive profile and metrics for disclosure quality attributes", Accounting Forum, Vol. 28 No. 3, pp. 205-236.

Beddewela, E. and Fairbrass, J. (2016), "Seeking legitimacy through CSR: Institutional pressures and corporate responses of multinationals in Sri Lanka", Journal of Business Ethics, Vol. 136 No. 3, pp. 503-522.

Beddewela, E. and Herzig, C. (2013), “Corporate social reporting by MNCs' subsidiaries in Sri Lanka”, Accounting Forum, Vol. 37 No. 2, pp. 135-149.

Belal, A.R. and Owen, D.L. (2007), "The views of corporate managers on the current state of, and future prospects for, social reporting in Bangladesh: an engagement-based study", Accounting Auditing and Accountability Journal, Vol. 20 No. 3, pp. 427-494.

Belanger, J., Berggren, C., Bjorkman, T. and Kohler, C. (1999), Being Local Worldwide: ABB and the Challenge of Global Management, Cornell University Press, London.

Beske, F., Haustein, E. and Lorson, P.C. (2020), "Materiality analysis in sustainability and integrated reports", Sustainability Accounting, Management and Policy Journal, Vol. 11 No. 1, pp. 162-186.

Biondi, L., Dumay, J. and Monciardini, D. (2020), "Using the international integrated reporting framework to comply with EU directive 2014/95/EU: can we afford another reporting façade?", Meditari Accountancy Research, Vol. 28 No. 5, pp. 889-914. 
MEDAR 29,7
Bondy, K. and Starkey, K. (2014), "The dilemmas of internationalization: corporate social responsibility in the multinational corporation”, British Journal of Management, Vol. 25 No. 1, pp. 4-22.

Bondy, K., Moon, J. and Matten, D. (2012), “An institution of corporate social responsibility (CSR) in multi-national corporations (MNCs): form and implications", Journal of Business Ethics, Vol. 111 No. 2, pp. 281-299.

Bowen, H.R. (1953), Social Responsibilities of the Businessman, Harper and Row, New York, NY.

Brammer, S. and Pavelin, S. (2005), "Corporate community contributions in the United Kingdom and the United States", Journal of Business Ethics, Vol. 56 No. 1, pp. 15-26.

Brammer, S., Jackson, G. and Matten, D. (2012), "Corporate social responsibility and institutional theory: new perspectives on private governance", Socio-Economic Review, Vol. 10 No. 1, pp. 3-28.

Burritt, R.L., Christ, K.L., Rammal, H.G. and Schaltegger, S. (2020), "Multinational enterprise strategies for addressing sustainability: the need for consolidation", Journal of Business Ethics, Vol. 164 No. 2, pp. 389-410.

Cahan, S.F., de Villiers, C.J., Jeter, D.C., Naiker, V. and van Staden, C.J. (2016), "Are CSR disclosures value relevant? Cross-country evidence", European Accounting Review, Vol. 25 No. 3, pp. 579-611.

Chapple, W. and Moon, J. (2005), "Corporate social responsibility (CSR) in Asia: a seven-country study of CSR web site reporting", Business and Society, Vol. 44 No. 4, pp. 415-441.

Chong, S., Ali, I. and Lodhia, S.K. (2016), "A model for gauging the prominence of web-based CSR disclosure", Pacific Accounting Review, Vol. 28 No. 4, pp. 431-445.

Christmann, P. (2004), "Multinational companies and the natural environment: determinants of global environmental policy standardization", Academy of Management Journal, Vol. 47 No. 5, pp. $747-760$.

CIA (2018), "The World Factbook", available at: www.cia.gov/the-world-factbook/

Danko, D., Goldberg, J.S., Goldberg, S.R. and Grant, R. (2008), "Corporate social responsibility: the United States vs. Europe”, Journal of Corporate Accounting and Finance, Vol. 19 No. 6, pp. 41-47.

Darnall, N., Henriques, I. and Sardorsky, P. (2010), "Adopting proactive environmental strategy: the influence of stakeholders and firm size”, Journal of Management Studies, Vol. 47 No. 6, pp. 1072-1094.

de Villiers, C. and Alexander, D. (2014), "The institutionalisation of corporate social responsibility reporting”, The British Accounting Review, Vol. 46 No. 2, pp. 198-212.

de Villiers, C. and Marques, A. (2016), "Corporate social responsibility, country-level predispositions, and the consequences of choosing a level of disclosure", Accounting and Business Research, Vol. 46 No. 2, pp. 167-195.

Deegan, C. and Unerman, J. (2011), Financial Accounting Theory, McGraw-Hill Companies Inc., New York, NY.

DiMaggio, P. and Powell, W. (1983), “The iron cage revisited: Institutional isomorphism and collective rationality in organizational fields", American Sociological Review, Vol. 48 No. 2, pp. 147-160.

Długopolska-Mikonowicz, A., Przytuła, S. and Stehr, C. (2019), "Corporate social responsibility in Poland: strategies, opportunities and challenges", CSR, Sustainability, Ethics and Governance, Springer: Switzerland.

Dögl, C. and Behnam, M. (2015), "Environmentally sustainable development through stakeholder engagement in developed and emerging countries", Business Strategy and the Environment, Vol. 24 No. 6, pp. 583-600, available at: https://doi.org/10.1002/bse.1839

Doni, F., Bianchi Martini, S., Corvino, A. and Mazzoni, M. (2019), "Voluntary versus mandatory nonfinancial disclosure: EU directive 95/2014 and sustainability reporting practices based on empirical evidence from Italy", Meditari Accountancy Research, Vol. 28 No. 5, pp. 781-802. 
Dumitru, M., Dyduch, J., Guse, R.G. and Krasodomska, J. (2017), "Corporate reporting practices in Poland and Romania - an ex-ante study to the new non-financial reporting European directive", Accounting in Europe, Vol. 14 No. 3, pp. 279-304.

Duran, J.J. and Bajo, N. (2014), "Institutions as determinant factors of corporate responsibility strategies of multinational firms", Corporate Social Responsibility and Environmental Management, Vol. 21 No. 6, pp. 301-317.

Dyduch, J. and Krasodomska, J. (2017), "Determinants of corporate social responsibility disclosure: an empirical study of Polish listed companies", Sustainability, Vol. 9 No. 11, p. 1934.

EC (2020a), "Corporate sustainability reporting. Public consultation”, available at: https://ec.europa.eu/ info/law/better-regulation/have-your-say/initiatives/12129-Revision-of-Non-Financial-ReportingDirective/public-consultation

EC (2020b), "Proposal for a regulation as regards disclosure of non-financial information by certain undertakings and groups", available at: https:/eur-lex.europa.eu/legal-content/DE/PIN/?uri= PI_COM:Ares(2020)580716

EC (2021), "Proposal for a directive of the European parliament and of the council amending directive 2013/34/EU, directive 2004/109/EC, directive 2006/43/EC and regulation (EU) no 537/2014, as regards corporate sustainability reporting", available at: https://eur-lex.europa.eu/legal-content/ EN/TXT/?uri=CELEX\%3A52021PC0189

Egri, C.P. and Ralston, D.A. (2008), "Corporate responsibility: a review of international management research from 1998 to 2007", Journal of International Management, Vol. 14 No. 4, pp. 319-339.

EU (2014), "Directive 2014/95/EU of the european parliament and of the council of 22 october 2014 amending directive 2013/34/EU as regards disclosure of non-financial and diversity information by certain large undertakings and groups", available at: https://eur-lex.europa.eu/legal-content/ EN/TXT/HTML/?uri=CELEX:32014L0095\&from=EN

Eweje, G. (2006), "The role of MNEs in community development initiatives in developing countries", Business and Society, Vol. 45 No. 2, pp. 93-129.

Farooq, M.B. and de Villiers, C. (2019), "Understanding how managers institutionalisesustainability reporting: evidence from Australia and New Zealand", Accounting, Auditing and Accountability Journal, Vol. 32 No. 5, pp. 1240-1269.

Feltham, S. (2016), “A snapshot of CSR in Central and Eastern Europe”, available at: www.triplepundit. com/2016/10/snapshot-csr-central-eastern-europe/

Fifka, M.S. (2013), "Corporate responsibility reporting and its determinants in comparative perspective - a review of the empirical literature and a Meta-analysis", Business Strategy and the Environment, Vol. 22 No. 1, pp. 1-35.

Fink, L. (2018), “A sense of purpose”, available at: www.blackrock.com/corporate/investor-relations/ larry-fink-ceo-letter

FOB (2017), "Nowe obowiązki prawne związane $z$ ujawnianiem informacji niefinansowych i polityki dotyczącej różnorodności. Analiza tematyczna”, available at: http:/odpowiedzialnybiznes.pl/ publikacje/nowe-obowiazki-prawne-zwiazane-ujawnianiem-informacji-niefinansowych-politykidotyczacej-roznorodnosci-analiza-tematyczna/

Garanina, T. and Dumay, J. (2017), "Forward-looking intellectual Capital disclosure in IPOs”, Journal of Intellectual Capital, Vol. 18 No. 1, pp. 128-148.

Governance and Accountability Institute, Inc (2018), "Navigating the way to sustainability", available at: www.ga-institute.com/press-releases/article/flash-report-85-of-sp-500-indexR-companiespublish-sustainability-reports-in-2017.html

Gray, R., Owen, D. and Adams, L.C. (1996), Accounting and Accountability: Changes and Challenges in Corporate Social and Environmental Reporting, Prentice Hall, London. 
MEDAR 29,7

Grayson, E.L. and Boye-Williams, P.L. (2011), "SEC disclosure obligations: Increasing scrutiny on environmental liabilities and climate change impacts", in Schnapf L.P. (Ed.), Environmental Issues in Business Transactions, ABA Book Publishing, Chicago, pp. 447-469.

GreenBiz Group (2018), "State of the rofession 2018 report", available at: www.greenbiz.com/report/ state-profession-2018-report

GRI (2020), "Sustainability disclosure database”, available at: https://database.globalreporting.org/ search/

Gruszewska, E. and Wakuluk, I. (2012), "Napływ bezpośrednich inwestycji zagranicznych do polski szanse rozwoju - scenariusze naprawcze", Zarządzanie i Finanse, Vol. 1 No. 1, pp. 263-272.

Harzing, A.W. and Noorderhaven, N.G. (2003), "The 'country-of-origin effect' in multinational corporations: Sources, mechanisms and moderating conditions", Management International Review, Vol. 43 No. 2, pp. 47-66.

Hofstede, G. (2020), "Hofstede insights", available at: www.hofstede-insights.com/product/comparecountries/

Holder-Webb, L., Cohen, J.R., Nath, L. and Wood, D. (2008), "The supply of corporate social responsibility disclosures among US firms", Journal of Business Ethics, Vol. 84 No. 4, pp. 497-527.

Hope, O.K., Kang, T., Thomas, W. and Yoo, Y.K. (2008), "Culture and auditor choice: a test of the secrecy hypothesis", Journal of Accounting and Public Policy, Vol. 27 No. 5, pp. 357-373.

Hummel, K., Schlick, C. and Fifka, M. (2017), "The role of sustainability performance and accounting assurors in sustainability assurance engagements", Journal of Business Ethics, Vol. 154 No. 3, pp. 733-757.

Husted, B. and Allen, D. (2006), "Corporate social responsibility in the multinational enterprise: strategic and institutional approaches", Journal of International Business Studies, Vol. 37 No. 6, pp. 838-849.

Islam, M.A. and Deegan, C. (2008), "Motivations for an organisation within a developing country to report social responsibility information", Accounting, Auditing and Accountability Journal, Vol. 21 No. 6, pp. 850-874.

Ismaeel, M. and Zakaria, Z. (2019), "Perception of preparers of sustainability reports in the Middle east: contrasting between local and global", Meditari Accountancy Research, Vol. 28 No. 1, pp. 89-116.

Ite, U.E. (2004), "Multinationals and corporate social responsibility in developing countries: a case study of Nigeria", Corporate Social Responsibility and Environmental Management, Vol. 11 No. 1, pp. 1-11.

Jamali, D. (2010a), "MNCs and international accountability standards through an institutional lens: evidence of symbolic conformity or decoupling”, Journal of Business Ethics, Vol. 95 No. 4, pp. 617-640.

Jamali, D. (2010b), "The CSR of MNC subsidiaries in developing countries: Global, local, substantive or diluted?", Journal of Business Ethics, Vol. 93 No. S2, pp. 181-200.

Jamali, D. and Neville, B., (2011), "Convergence versus divergence of csr in developing countries: an embedded multi-layered institutional lens", Journal of Business Ethics, Vol. 102Vol. 1. No. 4, pp. 599-621.

Jamali, D., Makarem, Y. and Willi, A. (2019), "From diffusion to translation: implementation of CSR practices in MNC subsidiaries", Social Responsibility Journal, Vol. 16 No. 3, pp. 309-327.

Kaymak, T. and Bektas, E. (2017), "Corporate social responsibility and governance: Information disclosure in multinational corporations", Corporate Social Responsibility and Environmental Management, Vol. 24 No. 6, pp. 555-569.

Kemp, M. (2001), "Corporate social responsibility in Indonesia: Quixotic dream or confident expectation?", Technology, Business and Society Program Paper No. 6, United Nations Research Institute for Social Development, Geneva, Switzerland. 
Khlif, H. (2016), "Hofstede's cultural dimensions in accounting research: a review", Meditari Accountancy Research, Vol. 24 No. 4, pp. 545-573.

KMPG and American Chamber of Commerce in Poland (2018), "American investments in Poland. Partnering to win in the next 100 years!", available at: https://assets.kpmg.com/content/dam/ $\mathrm{kpmg} / \mathrm{pl} / \mathrm{pdf} / 2018 / 04 /$ pl-raport-polska-ameryka_eng-online.pdf

Kolk, A. (2008), 'Sustainability, accountability and corporate governance: Exploring multinationals' reporting practices", Business Strategy and the Environment, Vol. 17 No. 1, pp. 1-15.

Kolk, A. and Fortanier, F. (2013), "Internationalization and environmental disclosure: the role of home and host institutions", Multinational Business Review, Vol. 21 No. 1, pp. 87-114.

Kostova, T., Roth, K. and Dacin, T. (2008), "Institutional theory in the study of multinational corporations: a critique and new directions", Academy of Management Review, Vol. 33 No. 4, pp. 994-1006.

Krasodomska, J. and Godawska, J. (2020), "CSR in Non-Large public interest entities: Corporate talk vs. Actions", Sustainability, Vol. 12 No. 21, p. 9075.

Krasodomska, J., Michalak, J. and Ś wietla, K. (2020), "Directive 2014/95/EU: Accountants' understanding and attitude towards mandatory non-financial disclosures in corporate reporting", Meditari Accountancy Research, Vol. 28 No. 5, pp. 751-779.

La Torre, M., Sabelfeld, S., Blomkvist, M. and Dumay, J. (2020), "Rebuilding trust: sustainability and non-financial reporting and the European union regulation", Meditari Accountancy Research, Vol. 28 No. 5, pp. 701-725.

Lear Corporation (2018), "Polityka firmy w zakresie ochrony środowiska oraz zdrowia i bezpieczeństwa pracowników", available at: www.lear.p1/lear-kultura-organizacyjna/ochrona-srodowiska

Lodhia, S. (2018), "Is the medium the message? Advancing the research agenda on the role of communication media in sustainability reporting", Meditari Accountancy Research, Vol. 26 No. 1, pp. 2-12.

Maignan, I. and Ralston, D.A. (2002), "Corporate social responsibility in Europe and the US: insights from business' self-presentations", Journal of International Business Studies, Vol. 33 No. 3, pp. $797-514$.

Mars (2018), "Zasady w działaniu - Mars w polsce. Podsumowanie 2015/2016”, available at: http:// zasadywdzialaniu.pl/MARS_zasady_w_dzialaniu.pdf

Martínez-Ferrero, J. and Frías-Aceituno, J.V. (2015), "Relationship between sustainable development and financial performance: International empirical research", Business Strategy and the Environment, Vol. 24 No. 1, pp. 20-39.

Matten, D. and Crane, A. (2005), "Corporate citizenship: toward an extended theoretical conceptualization”, Academy of Management Review, Vol. 30 No. 1, pp. 166-179.

Matten, D. and Moon, J. (2008), "Implicit and explicit CSR: a conceptual framework for a comparative understanding of corporate social responsibility", Academy of Management Review, Vol. 33 No. 2, pp. 404-424.

Matuszak, L. and Różańska, E. (2017), "CSR disclosure in polish-listed companies in the light of directive 2014/95/EU requirements: empirical evidence", Sustainability, Vol. 9 No. 12, p. 2304, available at: www.emerald.com/insight/content/doi/10.1108/SAMPJ-02-2020-0042/full/html

Matuszak, Ł. and Różańska, E. (2021), "Towards 2014/95/EU directive compliance: the case of Poland”, Sustainability Accounting, Management and Policy Journal, Vol. 12 No. 5.

Mazboudi, M., Sidani, Y.M. and Al Ariss, A. (2020), "Harmonization of firm CSR policies across national contexts: evidence from Brazil and Sweden", International Business Review, Vol. 29 No. 5, p. 101711.

Meyer, K. (2004), "Perspectives on multinational enterprises in emerging economies", Journal of International Business Studies, Vol. 35 No. 4, pp. 259-276. 
MEDAR

29,7

Michelon, G., Pilonato, S. and Ricceri, F. (2014), "CSR reporting practices and the quality of disclosure: an empirical analysis", Critical Perspectives on Accounting, Vol. 33, pp. 59-78.

Mohan, A. (2006), "Global corporate social responsibilities management in MNCs", Journal of Business Strategies, Vol. 23 No. 1, pp. 9-32.

Muller, A. (2006), "Global versus local CSR strategies", European Management Journal, Vol. 24 Nos 2/3, pp. 189-198.

Murcia, F.D. and Souza, F.C. (2010), "Social and environmental disclosure practices of Brazil", Revista de Economia e Administração, Vol. 9 No. 4, pp. 469-492.

Muthuri, J.N. and Gilbert, V. (2010), "An institutional analysis of corporate social responsibility in Kenya”, Journal of Business Ethics, Vol. 98 No. 3, pp. 467-483.

Oliver, C. (1997), "Sustainable competitive advantage: combining institutional and resource-based views", Strategic Management Journal, Vol. 18 No. 9, pp. 697-713.

Park, S.B. (2018), "Multinationals and sustainable development: does internationalization develop corporate sustainability of emerging market multinationals?", Business Strategy and the Environment, Vol. 27 No. 8, pp. 1514-1524.

Pepsico (2018), "Informacje dotyczące działań w zakresie społecznej odpowiedzialności (CSR) prowadzonych przez firme pepsico w polsce", available at: www.pepsicopoland.com/pl/files/ userfiles/files/DZIA $\%$ C5 $\% 81$ ANIA $\%$ 20PEPSICO $\% 20 \mathrm{~W} \%$ 20ZAKRESIE $\% 20 \mathrm{CSR} \% 20 \mathrm{~W}$ $\%$ 20POLSCE_wrzesie $\%$ C5\% 84\% 202017.pdf

Pfizer (2018), "Raport społecznej odpowiedzialności biznesu", available at: http://external.pfizer.com.pl/ raportCSR/\#page/1

Popowska, M. (2016), "Shaping new generations of managers and consumers: CSR implementation and higher education system in Poland", in Turker, D, Vural, C.A. and Idowu, S.O. (Eds), Social Responsibility Education across Europe. A Comparative Approach, Springer, Switzerland.

Porter, M.E. and Kramer, M.R. (2011), "Creating shared value”, Harvard Business Review, Vol. 89 No. 1, pp. 62-77.

Scott, W.R. (1987), "The adolescence of institutional theory”, Administrative Science Quarterly, Vol. 32 No. 4, pp. 493-511.

Scott, W.R. (2008), "Approaching adulthood: the maturing of institutional theory", Theory and Society, Vol. 37 No. 5 , pp. $427-442$.

Sharfman, M.P., Shaft, T.M. and Tihanyi, L. (2004), "A model of the global and institutional antecedents of high-level corporate environmental performance", Business and Society, Vol. 43 No. 1, pp. 6-36.

Simnett, R., Vanstraelen, A. and Chua, W.F. (2009), "Assurance on sustainability reports: an international comparison”, The Accounting Review, Vol. 84 No. 3, pp. 937-967.

Tejedo-Romero, F., Araujo, J.F.F.E. and Emmendoerfer, M.L. (2017), "Corporate governance mechanisms and intellectual Capital”, Review of Business Management, Vol. 19 No. 65, pp. 394-414.

Tran, M. and Beddewela, E. (2020), "Does context matter for sustainability disclosure? Institutional factors in southeast Asia", Business Ethics: A European Review, Vol. 29 No. 2, pp. 282-302.

U.S. Department of State (2020), "Investment climate statements. Customs report excerpts. Poland, bureau of economic and business affairs", available at: www.state.gov/report/custom/ 6fc0ee8d41-2/

Wanderley, L.S.O., Lucian, R., Farache, F. and de Sousa Fihlo, J.M. (2008), "CSR information disclosure on the web: a context-based approach analysing the influence of country of origin and industry sector", Journal of Business Ethics, Vol. 82 No. 2, pp. 369-378.

Wróbel, P. (2011), "Koncepcja izomorfizmu instytucjonalnego i jego przejawy w sektorze non-profit w wybranych krajach", Ekonomia Społeczna, Vol. 2, pp. 21-34. 


\begin{tabular}{|c|c|c|c|c|c|c|c|c|}
\hline No. & Country & Company name & $\mathrm{I}_{1}$ & $\mathrm{I}_{2}$ & $\mathrm{I}_{3}$ & $\mathrm{I}_{4}$ & $\mathrm{I}_{5}$ & \\
\hline \multirow[t]{2}{*}{1.} & US & GENERAL MOTORS COMPANY & 55.56 & 87.50 & 80.00 & 72.73 & 72.73 & 150 \\
\hline & PL & CHEVROLET POLAND SP. Z O.O & 11.11 & 0.00 & 0.00 & 0.00 & 3.03 & 159 \\
\hline \multirow[t]{2}{*}{2.} & US & PHILIP MORRIS INTERN. INC. & 88.89 & 62.50 & 80.00 & 9.09 & 54.55 & \\
\hline & PL & PHILIP MORRIS POLSKA S.A. & 0.00 & 12.50 & 20.00 & 45.45 & 21.21 & \\
\hline \multirow[t]{2}{*}{3.} & US & GOODYEAR TIRE and RUBBER & 66.67 & 75.00 & 40.00 & 27.27 & 51.52 & \\
\hline & PL & FIRMA OPONIARSKA DĘBICA S.A. & 44.44 & 0.00 & 0.00 & 27.27 & 21.21 & \\
\hline \multirow[t]{2}{*}{4.} & US & CITIGROUP & 66.67 & 75.00 & 60.00 & 45.45 & 60.61 & \\
\hline & PL & BANK HANDLOWY W WARSZAWIE S.A. & 11.11 & 25.00 & 20.00 & 18.18 & 18.18 & \\
\hline \multirow[t]{2}{*}{5.} & US & INTERNATIONAL PAPER & 66.67 & 87.50 & 40.00 & 63.64 & 66.67 & \\
\hline & PL & IP KWIDZYN"* & 77.78 & 37.50 & 20.00 & 9.09 & 36.36 & \\
\hline \multirow{2}{*}{6.} & US & PROCTER and GAMBLE CO. & 88.89 & 50.00 & 20.00 & 72.73 & 63.64 & \\
\hline & PL & PROCTER and GAMBLE POLSKA SP. Z O.O. & 44.44 & 25.00 & 20.00 & 27.27 & 30.30 & \\
\hline \multirow[t]{2}{*}{7.} & US & PEPSICO INC. & 66.67 & 62.50 & 60.00 & 36.36 & 54.55 & \\
\hline & PL & $\begin{array}{l}\text { PEPSI - COLA GENERAL BOTTLERS } \\
\text { POLAND SP. Z O.O. }\end{array}$ & 77.78 & 50.00 & 60.00 & 45.45 & 57.58 & \\
\hline \multirow[t]{2}{*}{8.} & US & 3M COMPANY & 77.78 & 75.00 & 40.00 & 72.73 & 69.70 & \\
\hline & PL & 3M POLAND SP. Z O.O. & 44.44 & 25.00 & 0.00 & 36.36 & 30.30 & \\
\hline \multirow[t]{2}{*}{9.} & US & WHIRLPOOL CORP. & 77.78 & 62.50 & 40.00 & 72.73 & 66.67 & \\
\hline & PL & WHIRLPOOL POLSKA SA & 0.00 & 0.00 & 0.00 & 0.00 & 0.00 & \\
\hline \multirow[t]{2}{*}{10.} & US & $\begin{array}{l}\text { INTERNATIONAL BUSINESS MACHINES } \\
\text { CORP }\end{array}$ & 77.78 & 62.50 & 40.00 & 72.73 & 66.67 & \\
\hline & PL & IBM POLSKA SP. Z O.O. & 11.11 & 50.00 & 20.00 & 27.27 & 27.27 & \\
\hline \multirow[t]{2}{*}{11.} & US & HEWLETT-PACKARD COMPANY & 66.67 & 75.00 & 80.00 & 63.64 & 69.70 & \\
\hline & PL & HEWLETT PACKARD POLSKA SP. Z O.O. & 0.00 & 0.00 & 0.00 & 0.00 & 0.00 & \\
\hline \multirow[t]{2}{*}{12.} & US & UNITED PARCEL SERVICE INC. & 66.67 & 87.50 & 20.00 & 63.64 & 63.64 & \\
\hline & PL & UPS POLSKA SP. Z O.O. & 33.33 & 50.00 & 0.00 & 18.18 & 27.27 & \\
\hline \multirow[t]{2}{*}{13.} & US & MARS INTERNATIONAL INC. & 88.89 & 87.50 & 60.00 & 63.64 & 75.76 & \\
\hline & PL & MARS POLSKA & 44.44 & 50.00 & 40.00 & 36.36 & 42.42 & \\
\hline \multirow[t]{2}{*}{14.} & US & FORD MOTOR CO. & 66.67 & 87.50 & 60.00 & 63.64 & 69.70 & \\
\hline & PL & FORD POLSKA SP. Z O.O. & 22.22 & 12.50 & 20.00 & 9.09 & 15.15 & \\
\hline \multirow[t]{2}{*}{15.} & US & MCDONALD'S CORPORATION & 55.56 & 37.50 & 40.00 & 36.36 & 42.42 & \\
\hline & PL & MCDONALD'S POLSKA SP. Z O.O. & 55.56 & 0.00 & 0.00 & 36.36 & 27.27 & \\
\hline \multirow[t]{2}{*}{16.} & US & GENERAL ELECTRIC COMPANY & 33.33 & 37.50 & 20.00 & 27.27 & 30.30 & \\
\hline & PL & BANK BPH S.A. & 0.00 & 0.00 & 0.00 & 0.00 & 0.00 & \\
\hline \multirow[t]{2}{*}{17.} & US & TRW AUTOMOTIVE HOLDINGS CORP. & 77.78 & 25.00 & 40.00 & 18.18 & 39.39 & \\
\hline & PL & TRW POLSKA SP.Z O.O. & 0.00 & 0.00 & 0.00 & 0.00 & 0.00 & \\
\hline \multirow[t]{2}{*}{18.} & US & COMMERCIAL METALS CO. & 55.56 & 37.50 & 80.00 & 45.45 & 51.52 & \\
\hline & PL & CMC POLAND SP. Z O.O. & 33.33 & 37.50 & 0.00 & 36.36 & 30.30 & \\
\hline \multirow[t]{2}{*}{19.} & US & $\begin{array}{l}\text { DESCENDANTS OF THE FOUNDING } \\
\text { CARGILL \&MACMILLAN FAMILIES }\end{array}$ & 55.56 & 50.00 & 40.00 & 45.45 & 48.48 & \\
\hline & PL & CARGILL POLAND SP. Z O.O. & 44.44 & 37.50 & 40.00 & 18.18 & 33.33 & \\
\hline \multirow[t]{2}{*}{20.} & US & AVON PRODUCTS INC. & 88.89 & 62.50 & 40.00 & 27.27 & 54.55 & \\
\hline & PL & AVON COSMETICS POLSKA SP. Z O.O. & 0.00 & 0.00 & 20.00 & 9.09 & 6.06 & \\
\hline \multirow[t]{2}{*}{21.} & US & UNITED TECHNOLOGIES CORPORATION & 77.78 & 50.00 & 40.00 & 27.27 & 48.48 & \\
\hline & PL & PZL-RZESZOW S.A. WYTWÓRNIA SPRZETU & 77.78 & 37.50 & 20.00 & 36.36 & 45.45 & Table A1. \\
\hline \multirow[t]{3}{*}{22.} & US & ARCHER-DANIELS-MIDLAND COMPANY & 66.67 & 50.00 & 40.00 & 45.45 & 51.52 & Companie \\
\hline & PL & ADM CZERNIN S.A. & 0.00 & 0.00 & 0.00 & 0.00 & 0.00 & disclosure indices \\
\hline & & & & & & $(\operatorname{con} t$ & inued) & \\
\hline
\end{tabular}




\section{MEDAR 29,7}

\begin{tabular}{|c|c|c|c|c|c|c|c|}
\hline No. & Country & Company name & $\mathrm{I}_{1}$ & $\mathrm{I}_{2}$ & $\mathrm{I}_{3}$ & $\mathrm{I}_{4}$ & $\mathrm{I}_{5}$ \\
\hline \multirow[t]{2}{*}{23.} & US & JOHNSON CONTROLS INC. & 66.67 & 50.00 & 40.00 & 63.64 & 57. \\
\hline & PL & $\begin{array}{l}\text { JOHNSON CONTROLS INTERNATIONAL SP. } \\
\text { Z O.O. }\end{array}$ & 0.00 & 0.00 & 0.00 & 0.00 & 0.00 \\
\hline \multirow[t]{2}{*}{24.} & US & TECH DATA CORP & 0.00 & 25.00 & 0.00 & 0.00 & 6.06 \\
\hline & PL & TECH DATA POLSKA SP. Z O.O. & 0.00 & 0.00 & 0.00 & 0.00 & 0.00 \\
\hline \multirow[t]{2}{*}{25.} & US & R. R. DONNELLEY and SONS COMPANY & 0.00 & 12.50 & 0.00 & 0.00 & 3.03 \\
\hline & PL & $\begin{array}{l}\text { R.R. DONNELLEY EUROPE } \\
\text { SP.Z O.O. }\end{array}$ & 0.00 & 0.00 & 0.00 & 0.00 & 0.00 \\
\hline \multirow[t]{2}{*}{26.} & US & LEAR CORP & 77.78 & 37.50 & 40.00 & 72.73 & 60.61 \\
\hline & PL & LEAR CORPORATION POLAND II SP. Z O.O. & 33.33 & 50.00 & 0.00 & 0.00 & 21.21 \\
\hline \multirow[t]{2}{*}{27.} & US & DENALI HOLDINGS, INC. & 0.00 & 0.00 & 0.00 & 0.00 & 0.00 \\
\hline & PL & DELL SP. Z O.O. & 11.11 & 25.00 & 20.00 & 0.00 & 12.12 \\
\hline \multirow[t]{2}{*}{28.} & US & UGI CORP & 0.00 & 12.50 & 0.00 & 45.45 & 18.18 \\
\hline & PL & AMERIGAS POLSKA SP. Z O.O. & 0.00 & 0.00 & 0.00 & 0.00 & 0.00 \\
\hline \multirow[t]{2}{*}{29.} & US & HAVI GROUP LIMITED PARTNERSHIP & 0.00 & 0.00 & 0.00 & 0.00 & 0.00 \\
\hline & PL & HAVI LOGISTICS SP. Z O.O. & 0.00 & 0.00 & 0.00 & 0.00 & 0.00 \\
\hline \multirow[t]{2}{*}{30.} & US & EXXO & 44.44 & 62.50 & 40.00 & 81.82 & 60.61 \\
\hline & PL & EXXONMOBIL POLAND SP. Z O. O. & 0.00 & 0.00 & 0.00 & 0.00 & 0.00 \\
\hline \multirow[t]{2}{*}{31.} & US & CHEVRON & 55.56 & 75.00 & 0.00 & 27.27 & 42.42 \\
\hline & PL & CHEVRON POLSK & 0.00 & 0.00 & 0.00 & 0.00 & 0.00 \\
\hline \multirow[t]{2}{*}{32.} & US & APPLE & 88.89 & 25.00 & 40.00 & 18.18 & 42.42 \\
\hline & PL & APPLE POLAND SP. Z O. O. & 0.00 & 0.00 & 0.00 & 0.00 & 0.00 \\
\hline \multirow[t]{2}{*}{33.} & US & PHILLIPS 66 & 88.89 & 87.50 & 40.00 & 36.36 & 63.64 \\
\hline & PL & PHILIPS POLSKA SP. Z O. O. & 0.00 & 0.00 & 0.00 & 0.00 & 0.00 \\
\hline \multirow[t]{2}{*}{34.} & US & AT\&T & 44.44 & 50.00 & 40.00 & 27.27 & 39.39 \\
\hline & PL & $\begin{array}{l}\text { AT\&T GLOBAL NETWORK SERVICES } \\
\text { POLSKA SP Z O.O. }\end{array}$ & 0.00 & 0.00 & 0.00 & 0.00 & 0.00 \\
\hline \multirow[t]{2}{*}{35.} & US & RCE BERGEN & 55.56 & 50.00 & 20.00 & 45.45 & 45.45 \\
\hline & PL & OLSKA SP Z O.O. & 0.00 & 12.50 & 0.00 & 9.09 & 6.06 \\
\hline \multirow[t]{2}{*}{36.} & US & MICR & 66.67 & 62.50 & 40.00 & 36.36 & 51.52 \\
\hline & PL & $\mathrm{MICl}$ & 11.11 & 0.00 & 0.00 & 18.18 & 9.09 \\
\hline \multirow[t]{2}{*}{37.} & US & JOHNSON and JOHNSON & 77.78 & 75.00 & 60.00 & 45.45 & 63.64 \\
\hline & PL & DSP.Z O.O. & 0.00 & 50.00 & 0.00 & 36.36 & 24.24 \\
\hline \multirow[t]{2}{*}{38.} & US & RATIONAL GROUP & 66.67 & 50.00 & 0.00 & 54.55 & 48.48 \\
\hline & PL & LIMITED SP. Z O.O & 0.00 & 0.00 & 0.00 & 0.00 & 0.00 \\
\hline \multirow[t]{2}{*}{39.} & US & METLIFE & 77.78 & 62.50 & 40.00 & 72.73 & 66.67 \\
\hline & PL & $\begin{array}{l}\text { METLIFE TOWARZYSTWO UBEZPIECZEN" } \\
\text { NA ŻYCIE I REASEKURACII S.A. }\end{array}$ & 0.00 & 0.00 & 0.00 & 0.00 & 0.00 \\
\hline \multirow[t]{2}{*}{40.} & US & GOOGLE & 77.78 & 25.00 & 20.00 & 45.45 & 45.45 \\
\hline & PL & IND SP. Z O.O. & 33.33 & 37.50 & 20.00 & 0.00 & 21.21 \\
\hline \multirow[t]{2}{*}{41.} & US & & 77.78 & 87.50 & 80.00 & 45.45 & 69.70 \\
\hline & PL & SP.Z O.O. & 33.33 & 12.50 & 0.00 & 9.09 & 15.15 \\
\hline \multirow[t]{2}{*}{42.} & US & CATE & 88.89 & 75.00 & 40.00 & 63.64 & 69.70 \\
\hline & PL & PILLAR POLAND SP. Z O.O. & 11.11 & 0.00 & 40.00 & 18.18 & 15.15 \\
\hline \multirow[t]{2}{*}{43.} & US & PFIZER & 77.78 & 50.00 & 40.00 & 18.18 & 45.45 \\
\hline & PL & OLSKA SP. Z O.C & 55.56 & 75.00 & 40.00 & 45.45 & 54.55 \\
\hline 44. & US & ION & 77.78 & 87.50 & 60.00 & 63.64 & 72.73 \\
\hline & PL & INTEL TECHNOLOGY POLAND SP. Z O. O. & 22.22 & 37.50 & 20.00 & 18.18 & 24.24 \\
\hline 45. & US & CISCO SYSTEMS, IN & 66.67 & 62.50 & 60.00 & 72.73 & 66.67 \\
\hline & PL & P.Z O.O. & 0.00 & 0.00 & 0.00 & 0.00 & 0.00 \\
\hline 46. & US & THE COCA-COLA COMPANY & 55.56 & 62.50 & 80.00 & 81.82 & 69.70 \\
\hline & PL & COCA-COLA HBC POLSKA SP. Z O.O. & 55.56 & 0.00 & 20.00 & 36.36 & 30.30 \\
\hline
\end{tabular}

Table A1. 


\begin{tabular}{|c|c|c|c|c|c|c|c|c|}
\hline No. & Country & Company name & $\mathrm{I}_{1}$ & $\mathrm{I}_{2}$ & $\mathrm{I}_{3}$ & $\mathrm{I}_{4}$ & $\mathrm{I}_{5}$ & \\
\hline \multirow[t]{2}{*}{47.} & US & LOCKHEED MARTIN CORPORATION & 55.56 & 75.00 & 40.00 & 9.09 & 42.42 & \\
\hline & PL & $\begin{array}{l}\text { LOCKHEED MARTINGLOBAL INC. (S.A.) } \\
\text { ODDZIAL W POLSCE }\end{array}$ & 0.00 & 0.00 & 0.00 & 0.00 & 0.00 & \\
\hline \multirow[t]{2}{*}{48.} & US & THE WALT DISNEY COMPANY & 77.78 & 75.00 & 60.00 & 90.91 & 78.79 & \\
\hline & PL & $\begin{array}{l}\text { THE WALT DISNEY COMPANY POLSKA SP. } \\
\text { Z O.O. }\end{array}$ & 0.00 & 0.00 & 0.00 & 0.00 & 0.00 & 161 \\
\hline \multirow[t]{2}{*}{49.} & US & FEDEX CORPORATION & 55.56 & 75.00 & 0.00 & 54.55 & 51.52 & \\
\hline & PL & FEDEX EXPRESS POLSKA SP. Z O.O. & 55.56 & 25.00 & 0.00 & 36.36 & 33.33 & \\
\hline \multirow[t]{2}{*}{50.} & US & MERCK and CO., INC. & 55.56 & 75.00 & 60.00 & 72.73 & 66.67 & \\
\hline & PL & MERCK SP. Z O.O. & 11.11 & 0.00 & 0.00 & 18.18 & 9.09 & \\
\hline \multirow{2}{*}{51.} & US & INGRAM MICRO INC. & 55.56 & 75.00 & 40.00 & 54.55 & 57.58 & \\
\hline & PL & INGRAM MICRO SP. Z O.O. & 0.00 & 0.00 & 0.00 & 0.00 & 0.00 & \\
\hline \multirow[t]{2}{*}{52.} & US & PRUDENTIAL FINANCIAL, INC & 33.33 & 62.50 & 40.00 & 45.45 & 45.45 & \\
\hline & PL & $\begin{array}{l}\text { PRAMERICA ŻYCIE TOWARZYSTWO } \\
\text { UBEZPIECZEN" I REASEKURACJI S.A. }\end{array}$ & 0.00 & 25.00 & 0.00 & 27.27 & 15.15 & \\
\hline \multirow[t]{2}{*}{53.} & US & THE GOLDMAN SACHS GROUP, INC. & 77.78 & 75.00 & 20.00 & 54.55 & 60.61 & \\
\hline & PL & $\begin{array}{l}\text { GOLDMAN SACHS POLAND SERVICES SP. Z } \\
\text { O.O }\end{array}$ & 0.00 & 0.00 & 0.00 & 0.00 & 0.00 & \\
\hline \multirow[t]{2}{*}{54.} & US & $\begin{array}{l}\text { LIBERTY MUTUAL HOLDING COMPANY } \\
\text { INC. }\end{array}$ & 0.00 & 25.00 & 0.00 & 9.09 & 9.09 & \\
\hline & PL & LIBERTY POLANDS.A. & 0.00 & 0.00 & 0.00 & 0.00 & 0.00 & \\
\hline \multirow[t]{2}{*}{55.} & US & HONEYWELL INTERNATIONAL INC. & 66.67 & 62.50 & 80.00 & 36.36 & 57.58 & \\
\hline & PL & HONEYWELL SP. Z O. O. & 0.00 & 0.00 & 0.00 & 0.00 & 0.00 & \\
\hline \multirow[t]{2}{*}{56.} & US & DEERE\&COMPANY & 33.33 & 50.00 & 0.00 & 27.27 & 30.30 & \\
\hline & PL & JOHN DEERE POLSKA SP. Z O. O. & 0.00 & 0.00 & 0.00 & 0.00 & 0.00 & \\
\hline \multirow[t]{2}{*}{57.} & US & ORACLE CORPORATION & 100.00 & 75.00 & 40.00 & 72.73 & 75.76 & \\
\hline & PL & ORACLE POLSKA SP.Z O. O. & 0.00 & 0.00 & 0.00 & 0.00 & 0.00 & \\
\hline \multirow[t]{2}{*}{58.} & US & MORGAN STANLEY & 77.78 & 75.00 & 20.00 & 54.55 & 60.61 & \\
\hline & PL & $\begin{array}{l}\text { MORGAN STANLEY and CO } \\
\text { INTERNATIONAL PLC (S.A.) ODDZIAL W } \\
\text { POLSCE }\end{array}$ & 0.00 & 0.00 & 0.00 & 0.00 & 0.00 & \\
\hline \multirow[t]{2}{*}{59.} & US & E.I. DU PONT DE NEMOURS AND COMPANY & 66.67 & 75.00 & 40.00 & 36.36 & 54.55 & \\
\hline & PL & DUPONT POLAND SP. Z O.O. & 22.22 & 0.00 & 0.00 & 18.18 & 12.12 & \\
\hline \multirow[t]{2}{*}{60.} & US & AMERICAN EXPRESS COMPANY & 66.67 & 75.00 & 60.00 & 72.73 & 69.70 & \\
\hline & $\mathrm{PL}$ & AMERICAN EXPRESS POLAND SP.Z O. O. & 0.00 & 0.00 & 0.00 & 0.00 & 0.00 & Table A1. \\
\hline
\end{tabular}


MEDAR

29,7

162
Appendix 2

$\mathrm{I}_{1}$ - Environmental impacts disclosure index (nine items)

Ecology - promotion

Water - save

Emissions - reduction

Energy use - reduction

Waste - reduction

Recycling

Environment protection - investments

Natural disasters prevention

Environmental KPIs

I3 - Relations with partners disclosure index (five items)

Relations with partners (suppliers and clients)

Responsibility for products

Clients' satisfaction analyzes

Responsible marketing

Partners KPIs

Table A2.

Items included in the disclosure indices

$\mathrm{I}_{5}$ - Overall disclosure index (all 33 items)
$\mathrm{I}_{2}-$ Employees and work environment disclosure index (eight items)

Employee-friendly environment

Diversity at the workplace

Anti-corruption policy

Ethics

Volunteering

Occupational safety and health

Labor unions

Employees KPIs

I4 - Community involvement-related disclosure index (11 items)

Charity and sponsorships (general)

Health protection

Sport

Culture

Educational initiatives

Help disabled and people in need

Better life conditions

Help - natural disasters

Women support

Entrepreneurship support

Local communities KPIs

\section{Corresponding author}

Joanna Krasodomska can be contacted at: joanna.krasodomska@uek.krakow.pl

For instructions on how to order reprints of this article, please visit our website: 